\title{
Berbagi suami atas nama Tuhan: pengalaman keseharian perempuan dipoligami di Langsa
}

\author{
Muhammad Ansor \\ Sekolah Tinggi Agama Islam Negeri Zawiyah Cot Kala Langsa \\ E-mail:ansor_riau@yahoo.co.id
}

This article explores how daily experience of the women living in the polygamous family in Langsa, Aceh. The primary argument proposed in this paper is that conflict, in fact, emerges from husband decision to practice polygamy in domestic life despite the belief of some women who accept that Islam countenances the practice of polygamy. The conflict sometimes arises among wives, between husband and the wives or among children of different wives. To prove such argument, the investigation of the daily experience of polygamous family such as the relation among the wives, household financial management, articulation of fairness on both physical and spiritual fulfilment, celebration of religious days ( $I d u l$ Fitri and $I d u l ~ A d h a)$, as well as upbringing of children was carried out during second semester of 2011. The data was collected through semi-structured interview, observation to the domestic life of the polygamous family, and documentation on divorce suit as a result of practiced polygamy. This study revealed that peaceful family (keluarga sakinah) as often regarded as one of the ultimate goals of marriage would never be attained through such practice.

Tulisan berikut mengeksplorasi pengalaman keseharian perempuan dalam keluarga poligami di Langsa, Aceh. Argumen pokok yang diajukan adalah meskipun sebagian perempuan dipoligami mempercayai pernikahan poligami dibolehkan Islam, namun konflik akibat keputusan suami berpoligami memenuhi lanskap kehidupan rumah tangga mereka. Konflik terkadang berlangsung antara sesama istri, antara suami dengan para istrinya, ataupun antara sesama anak dari istri yang berbeda. Untuk membuktikan argumen tersebut, penulis menelusuri pengalaman keseharian keluarga poligami, baik menyangkut relasi antar para istri, pengelolaan ekonomi rumah tangga, artikulasi konsepsi adil baik secara batiniah dan lahiriah, pengalaman ketika perayaan hari besar agama (idul Fitri dan idul Adha), dan perkembangan anak. Data dikumpulkan selama semester kedua tahun 2011, melalui wawancara semi-terstruktur, observasi kehidupan keseharian keluarga dipoligami, dan penelusuran dokumentasi tentang gugatan perceraian karena suami berpoligami. Penelitian ini menyimpulkan bahwa keluarga sakinah yang seringkali 
ljthad, Jurnal Wacana Hukum Islam dan Kemanusiaan, Volume 14, No. 1, Juni 2014: 41-63

dianggap sebagai salah satu tujuan utama perkawinan tidak akan pernah didapatkan dalam pernikahan poligami.

Keywords : Women; Marriage; Polygamous Family; Langsa

\section{Pendahuluan}

Poligami merupakan isu sosial yang cukup problematik di Indonesia (Huda, 2010: 55; Robinson, 2009:176-187). Walaupun menganut asas perkawinan monogami, namun undangundang perkawinan Indonesia juga mengatur kemungkinan suami menambah istri. Mayoritas Muslim—termasuk sebagian intelektual dan ulama di Indonesia-mempercayai 'Islam membolehkan poligami' (Adnan, 2004: 176), bahkan sebagian mereka beranggapan 'poligami dianjurkan dalam Islam' (Nasir, 2009: 26; Irawan, 2007:60). Namun demikian, legalitas poligami selalu mendapatkan penentangan keras dari sebagian aktivis feminis Muslim di Indonesia.

Islam bukan agama yang sepi dari perlawanan terhadap praktik poligami. Perlawanan perempuan terhadap poligami sudah ditemukan sejak masa dinasti Umayah (Mernissi, 1999:152). Mernissi mencatat, Sakinah binti Husein, cucu perempuan Nabi, berhasil memaksa suaminya yang ketiga, cucu laki-laki Usman Ibn Affan, untuk menaati monogami. Sakinah bahkan melarang suaminya mendekati wanita lain, termasuk jawari-nya sendiri. Sakinah menceraikan suaminya meskipun hal itu menimbukan skandal besar, ketika dia memergoki suaminya bersama salah seorang jawari-nya yang dimiliki sesuai dengan aturan yang ditetapkan.

Mernissi, merupakan salah satu feminis Muslim kontemporer yang cukup keras dalam menentang praktik poligami. Poligami menurut Mernissi (1997:112) merupakan salah satu cara bagi laki-laki untuk merendahkan wanita secara seksual. Selain Mernissi, Siti Musdah Mulia aktivis feminis Muslim Indonesia juga tercatat sebagai penentang poligami. Pada 2004, Mulia bersama koalisi organisasi perempuan yang berbasis di Jakarta mengajukan Counter Legal Draft Kompilasi Hukum Islam di Indonesia, yang berisi tuntutan agar negara menerbitkan undang-undang yang mengatur larangan poligami (Mulia, 2005). Meski tuntutan tersebut diabaikan pemerintah, dalam diskursus di ruang publik Indonesia, aktivis Muslim penentang poligami cukup aktif memperjuangkan aspirasi mereka. 
Berbagi suami atas nama Tuhan: pengalaman keseharian perempuan dipoligami... (Muhammad Ansor)

Perempuan Langsa memperlihatkan pandangan beragam menyangkut kebolehan poligami dalam Islam. Seorang perempuan yang belum menikah mengatakan poligami dibenarkan Islam meskipun dirinya secara pribadi sangat menentang dan menceraikan suaminya yang berpoligami (Wawancara Wati, 2011). Perempuan lainnya mengatakan poligami sebagai takdir Tuhan atas dirinya yang tidak mungkin dapat ditolak kendati secara pribadi dirinya tidak setuju (Wawancara Sofi, 2011). Ada juga yang tidak mempersoalkan dan merelakan suaminya berpoligami karena mempercayai Islam membolehkan poligami. Berdasarkan survey yang dilakukan di Langsa, mayoritas perempuan mempercayai poligami sejalan dengan ajaran Islam (Ansor, 2010; bandingkan Hoesterey, 2012: 97).

Meskipun meyakini Islam membolehkan poligami, perempuan Langsa umumnya menolak dipoligami dan memilih pernikahan monogami. Ini tercermin dalam banyaknya jumlah gugatan perceraian yang diajukan perempuan Langsa karena suami mereka menambah istri. Aminah (2011) mencatat selama 2010, sebanyak 20 gugatan perceraian karena poligami mendapat persetujuan Mahkamah Syariah Langsa. Kasus ini meliputi poligami yang sejak semula diketahui istri maupun poligami yang di setelah beberapa waktu pernikahan dilakukan baru terendus istri. Gugatan perceraian tersebut mengindikasikan penolakan perempuan terhadap praktik poligami.

Perempuan dan poligami dalam Islam bukan penelitian yang sama sekali baru. Nina Nurmila (2009), Taha A.Z. Yamani (2008), dan Susan Blackburn (2004) merupakan beberapa di antara intelektual yang menghabiskan banyak waktu untuk menekuni tema ini. Disertasi Nurmila yang kemudian diterbitkan dengan judul Women, Islam and Everyday Life: Renegosiation Poligamy in Indonesia menyoroti negosiasi perempuan Muslim terhadap legalitas poligami dengan mendasarkan pada pengalaman keseharian perempuan dipoligami di Jawa. Nurmila berargumen poligami sejatinya bukan perintah agama Islam dan juga bukan praktik yang sejalan dengan nilai-nilai Islam. Nurmila memperlihatkan, resistensi perempuan terhadap poligami menunjukkan upaya mereka menegosiasikan kembali legalitas poligami dalam Islam.

Penelitian sejenis dilakukan Yamani dengan menyoroti praktik poligami di Hijaz, salah satu daerah di Arab Saudi. Menurut Yamani, poligami pada mulanya merupakan fenomena kemanusiaan yang seringkali dihubungkan dengan praktik budaya umat Yahudi yang kemudian berkembang luas seiring dengan kemunculan Islam (Yamani, 2008: 238, bandingkan Rhouni, 
ljthad, Jurnal Wacana Hukum Islam dan Kemanusiaan, Volume 14, No. 1, Juni 2014: 41-63

2010: 171). Yamani menegaskan bahwa meluasnya praktik poligami dalam masyarakat Hijaz kontemporer selain didorong oleh lingkungan budaya masyarakat Arab, juga mendapatkan momentum dengan 'adanya regulasi yang membolehkan poligami serta dukungan elite agama dalam menafsirkan doktrin agama Islam'. Meluasnya praktik poligami dalam masyarakat Arab kontemporer merupakan 'gambaran menguatkan pembatasan dan tekanan sosial terhadap perempuan dalam kehidupan keseharian mereka' (Yamani, 2008: 239-46).

Blackburn (2004:111-37) dalam karyanya berjudul Women and the State in Modern Indonesia membahas poligami dari sudut pandang feminis. Blackburn tidak sekedar menginvestigasi sejarah praktik poligami di Indonesia teNamun juga mengetengahkan sebuah diskursus kritis soal poligami dengan berjangkar pada tujuan-tujuan ideologis feminis, yakni penentangan terhadap poligami. Menurutnya sebagian perempuan Indonesia menentang keras poligami. Sejalan dengan Nurmila dan Yamani, Balckburn berkesimpulan bahwa hegemoni patriarkhi dalam penafsiran doktrin agama sangat mewarnai corak penyusunan undang-undang Perkawinan di Indonesia.

Penelitian ini akan memperkaya perspektif Nurmila, Yamani dan Blackburn dengan mengetengahkan etnografi pengalaman keseharian perempuan dipoligami di Langsa, Aceh. Argumen pokok yang diajukan adalah: betapapun sebagian besar perempuan dipoligami mempercayai poligami dibolehkan dalam Islam, namun pada saat bersamaan mayoritas perempuan sesungguhnya tidak setuju dengan keputusan suami berpoligami. Karenanya, ketika mereka 'terpaksa' harus terlibat dalam pernikahan poligami, maka konflik dan ketegangan selalu memenuhi lanskap kehidupan rumah tangga mereka. Tulisan ini berargumen bahwa keluarga sakinah yang seringkali dianggap sebagai salah satu tujuan utama perkawinan tidak akan didapatkan pasangan poligami.

Untuk memperkuat argumen yang diajukan, pertama-tama akan saya akan menjelaskan metode yang digunakan dalam penelitian. Selanjutnya akan dipaparkan sketsa praktik poligami di Langsa. Pembahasan dilanjutkan dengan mengulas pengalaman perempuan dipoligami dengan berfokus lima isu berikut: relasi para istri dalam keluarga dipoligami; pengelolaan ekonomi rumah tangga; artikulasi adil dan pengaturan jadwal untuk para istri; perayaan 'Idul Fitri dan Idul Adha; dan perkembangan anak dalam keluarga poligami. Tulisan diakhiri dengan penutup yang berisi simpulan dan rekomendasi yang relevan dengan temuan penelitian. 
Berbagi suami atas nama Tuhan: pengalaman keseharian perempuan dipoligami... (Muhammad Ansor)

\section{Metode penelitian}

Jenis penelitian berikut adalah penelitian kualitatif dengan menggunakan pendekatan fenomenologi. Peneliti berusaha memberikan deskripsi kehidupan keseharian perempuan dipoligami berdasarkan perspektif fenomenologis. Lazimnya penelitian fenomenologis, peneliti tidak dalam posisi memberi justifikasi moral atau pun hukum terhadap praktik poligami, melainkan 'sekedar' menyajikan deskripsi pengalaman kehidupan keluarga poligami dari sudut pandang perempuan (Lihat Erricker, 2002: 117).

Pengumpulan data dilakukan melalui wawancara semi-terstruktur, observasi dan studi dokumentasi selama semester kedua tahun 2011. Penulis mewawancari perempuan dipoligami, terdiri lima orang perempuan berstatus istri pertama maupun istri kedua serta seorang suami partisipan poligami. Penulis juga mewawancarai lingkungan terdekat partisipan poligami, seperti anak, saudara, tetangga, dan seorang Imam meunasah (musholla) yang biasa menjadi tempat konsultasi partisipan poligami dalam mendiskusi masalah keluarga. Wawancara didesain dengan fokus utama menelusuri pengalaman mereka dalam kehidupan poligami terutama terkait dengan hubungan sesama istri, pengelolaan ekonomi keluarga, artikulasi adil, dan perkembangan anak dalam keluarga poligami. Nama-nama informan yang disebutkan dalam tulisan ini sudah pasti disamarkan untuk memastikan kenyamanan mereka.

Mengenai observasi, selama pengumpulan data peneliti melakukan pengamatan mendetail dan berkesinambungan tentang dinamika kehidupan keseharian dua keluarga poligami. Adapun terkait teknik dokumentasi, peneliti menelusuri berkas kasus poligami yang diajukan di Mahkamah Syariah Langsa tahun 2010-2011. Data-data tentang surat gugatan perceraian, risalah persidangan, pembelaan tergugat merupakan informasi yang sangat membantu peneliti mengkonstruksi potret poligami di Langsa.

Analisisa dimulai sejak pengumpulan data. Hasil wawancara diuji silang melalui komentar responden yang berbeda (suami atau istri) untuk memastikan akurasi data yang didapatkan. Karena itu, peneliti terkadang melakukan wawancara lebih dari tiga kali dengan seorang informan. Tujuannya untuk memperkokoh dan memperluas bukti yang dijadikan landasan pengambilan kesimpulan tentang fenomena poligami di Langsa. 
ljthad, Jurnal Wacana Hukum Islam dan Kemanusiaan, Volume 14, No. 1, Juni 2014: 41-63

\section{Sketsa praktik poligami di Langsa}

Perlu kerja keras untuk mendapatkan gambaran akurat mengenai statistik poligami di Langsa. Gagasan ingin mendapatkan data yang akurat akan berakhir mengecewakan. Terkecuali karena tidak pernah dilakukan sensus poligami, juga disebabkan 'sebagian besar poligami dilakukan diam-diam' (Chin, 2012:140-1) atau tidak resmi (Nurmila, 2009). Hanya sebagian kecil saja partisipan pernikahan poligami yang tercatat dalam kantor catatan sipil di Langsa. Hal ini agaknya karena di Indonesia, 'poligami hanya diakui kantor catatan sipil apabila mendapatkan izin tertulis dari istri sebelumnya' (Vignato, 2012: 253). Selama 2010-2011 misalnya, hanya tercatat dua orang yang mengajukan izin poligami ke Mahkamah Syariah Langsa, sementara puluhan perempuan Langsa mengajukan gugatan perceraian karena suami berpoligami. Statistik pernikahan poligami diperkirakan jauh lebih besar dari jumlah perempuan yang mengajukan gugatan ke pengadilan.

Untuk sekedar sketsa, saya akan menggambarkan fenomena poligami di sekitar lingkungan tempat tinggal saya, di desa Seulalah Baru, dan di Mahkamah Syariah Langsa. Sekitar radius 250 meter dari rumah saya, sedikitnya ada enam perempuan dipoligami, baik sebagai istri pertama maupun istri kedua. Rumah tempat tingga saya dapat diakses dari tiga arah, jalan sebelah barat, timur dan selatan. Dari jalan sebelah barat ada satu orang berstatus sebagai istri pertama dan seorang berstatus istri kedua. Bagian timur rumah saya terdapat dua perempuan dipoligami: seorang berstatus istri pertama dan lainnya sebagai istri kedua. Sementara di sebelah selatan terdapat seorang perempuan berstatus istri pertama dan satu orang berstatus sebagai istri kedua. Fakta sederhana ini menunjukkan poligami merupakan fenomena keseharian yang mudah ditemukan.

Sketsa poligami di Mahkamah Syariah, antara lain terlihat ketika Zainab (32 tahun) yang menggugat cerai Maulud (43 tahun) karena berpoligami. Maulud menikahi tiga perempuan, yakni secara berurutan Anggita, Zainab, dan Ramadani. Sebelum pernikahan dengan Zainab, Maulud 'telah memiliki istri' (Anggita). Seiring permasalahannya dengan Zainab, Maulud menikahi Ramadani. Namun Maulud tidak mendaftarkan pernikahan poligaminya dengan Zainab dan Ramadani di kantor pencatatan sipil. Karenanya ketika Zainab mengajukan gugatan perceraian, saat bersamaan dirinya juga mengajukan permohonan isbat (pengakuan) nikah. Alasan Zainab mengajukan gugatan perceraian dikarenakan 'telah terjadi percekcokan 
Berbagi suami atas nama Tuhan: pengalaman keseharian perempuan dipoligami... (Muhammad Ansor)

dan perselisihan yang terus menerus', 'tergugat telah kawin lagi dengan dua orang wanita lain' dan 'memiliki sifat kasar serta suka menghina keluarga penggugat', sehingga Zainab merasa tidak lagi dapat melanjutkan pernikahannya.

Fenomena di Seulalah dan kisah Maulud merupakan potret kontemporer tentang poligami di Langsa. Agar pemaparan lebih informatif, saya akan menelusuri praktik poligami di Aceh sekitar dua abad sebelumnya. Adalah fenomena umum bahwa seorang raja di Aceh, demikian halnya di tempat lain di Nusantara, digambarkan memiliki istri lebih dari seorang. Mereka digambarkan mengumpulkan para istri ataupun gundik untuk tinggal di istana. Teks-teks tentang Aceh abad XVII menggambarkan kisah-kisah keindahan istana pada masa Iskandar Muda berupa paduan antara kemewahan bangunan fisik dan para perempuan yang mendiaminya. Augustin de Beaulieu, seorang pelancong Perancis yang berada di Aceh selama 1620-1621 sebagaimana dikutip Lombart (2008: 84) membuat deskripsi fenomena poligami pada masa pemerintahan Iskandar Muda.

"Sesuai dengan hukum Muhammad, mereka memperistri perempuan sebanyak yang mereka inginkan atau dapat mereka hidupi, teNamun salah satu dari perempuan itu adalah istri utama dan anak-anaknyalah yang menjadi pewaris yang sah; mereka tidak memperlihatkan istri mereka atau mengizinkannya ke luar rumah, teNamun yang boleh keluar ialah budak dan beberapa selir mereka. Si Suami biasanya memperistri dara muda dan ia harus membayar untuk memperolehnya dari orang tuanya, dan harus memberinya sebagian dari harta bendanya, sebagai warisan (Lombart, 2008:84).

Beaulieu menggambarkan orang-orang kaya dan penguasa bebas menikahi perempuan sesuai jumlah yang diinginkan. Jumlah istri atau gundik berbanding urus dengan tingkat status sosial laki-laki. Sayangnya Beaulieu tidak menginformasikan fenomena poligami masyarakat awam. Fenomenana poligami tidak mengalami perubahan berarti dua abad kemudian. Hurgronje melaporkan, 'yang paling sering melakukan poligami adalah kalangan bangsawan (tuanku), hulubalang dan penguasa lainnya, dan guru agama atau orang-orang terpandang karena kesalehan atau pun pendidikannya' (Hugronje, 1985: 401-2). Kepada mereka ini, lanjut Hurgjonje, 'orang-orang Aceh dengan senang hati mengawinkan puterinya, walaupun hanya menjadi istri kedua, ketiga atau bahkan keempat'.

Hurgronje dan Beaulieu sependapat mengenai poligami sebagai fenomena elite di Aceh. Hanya saja jangkauan pengamatan Hurgronje sedikit lebih luas dengan mengatakan orang- 
ljthad, Jurnal Wacana Hukum Islam dan Kemanusiaan, Volume 14, No. 1, Juni 2014: 41-63

orang seperti hulu balang dan guru agama sebagai pelaku poligami selain para penguasa. Tidak tersedia catatan poligami di kalangan masyarakat biasa. Namun pada masa sekarang, fenomena poligami tidak hanya dilakukan elite, Namun juga masyarakat biasa. Salah satu suami partisipan poligami yang menjadi informan studi ini berprofesi penjual rujak keliling. Bagaimanapun, secara umum tidak ada perbedaan signifikan menyangkut perilaku poligami dalam masyarakat Aceh selama dua abad terakhir. Menurut Zeitzen (2008:70-1) poligami sebetulnya merupakan praktik yang sudah sejak lama ditemukan dalam masyarakat Melayu (termasuk Aceh) dan masih tetap berlangsung hingga sekarang.

\section{Perempuan dalam pernikahan poligami}

Sesi berikut akan menginvestigasi pengalaman perempuan dalam keluarga poligami. Saya akan memaparkan potret keseharian perempuan dipoligami dengan berfokus pada relasi para istri, menajemen ekonomi keluarga, artikukasi perayaan hari besar agama, dan perkembangan anak dalam lingkungan keluarga dipoligami. Sesi ini bermaksud memberikan gambaran bahwa perempuan dipoligami seringkali mengalami situasi yang sulit akibat relasi yang tidak seimbang antara dirinya dan suami.

\section{Relasi para istri dalam keluarga poligami}

Poligami sangat berdampak terhadap pola relasi sosial antara sesama istri dipoligami (Altman, 1996: 366; Yamani, 2008: 163-204). Sarah Hicks (2008) menggambarkan hubungan antar sesama istri dipoligami sebagai hubungan yang rumit dan pelik. Nurmila (2009:116) membagi relasi antara istri yang dipoligami ke dalam empat kategori. Pertama, para istri tidak pernah saling bertemu satu sama lain meskipun keduanya mengetahui bersuami orang yang sama. Kedua, para istri pernah berkomunikasi satu sama lain meskipun hanya melalui telepon, tanpa pernah bertemu secara langsung. Ketiga, para istri saling mengenal dan pernah berkomunikasi satu sama lain kendati hubungan antara kedua tidak berlangsung baik. Keempat, hubungan antara para istri secara umum berlangsung relatif baik, meskipun selalu diwarnai kecemburuan dan ketegangan antara para istri.

Kategorisasi yang dikemukakan Nurmila cukup membantu saya mendeskripsikan pola relasi para istri dalam keluarga poligami meskipun tidak semua kategorisasi tersebut saya 
temukan dalam penelitian di Langsa. Terkait kategorisasi pertama, di Seulalah, Kecamatan Langsa Lama, satu dari enam perempuan yang dipoligami tidak pernah bertemu dengan istri muda suaminya, meskipun dirinya mengetahui suaminya sudah beristri lagi. Hindun, nama disamarkan, mengatakan dirinya tidak berminat mengenal istri muda suaminya karena dirinya khawatir apabila sewaktu-waktu secara tidak sengaja bertemu dengan istri kedua suaminya di tempat umum dirinya dia tidak dapat mengontrol emosinya. Dia memilih tidak ingin pernah mengenal istri kedua suaminya agar "tidak mencakar-cakar anak orang" (Wawancara Hindun, 12 November 2011).

Selanjutnya, saya juga menemukan contoh relasi para istri dalam keluarga poligami yang dikategorisasi model kedua. Seorang rekan kerja saya, Malizar (laki-laki, 34 tahun), yang merupakan anak hasil pernikahan poligami dari istri kedua, mengatakan dahulu ayahnya berpoligami karena alasan ingin mendapatkan anak perempuan. Tiga orang anak yang dilahirkan dari istri sebelumnya, semuanya laki-laki. Tanpa sepengetahuan istrinya, dia berpoligami dengan harapan mendapatkan anak perempuan. Ketika poligaminya terbongkar, istri pertama meminta suaminya berkomitmen tidak membawa pulang istri keduanya ke desa. Komitmen tersebut disepakati suami, sehingga pertemuan antara para istri tersebut tidak pernah terjadi hingga istri pertama meninggal dunia (Wawancara Malizar, 19 November 2011). Pengalaman poligami ayah Malizar memperlihatkan contoh hubungan yang minimalis antara para istri dalam pernikahan poligami.

Model relasi ketiga adalah hubungan di mana istri pertama dan kedua saling melakukan komunikasi, bahkan saling mengenal satu sama lain, meski hubungan tersebut tidak berlangsung secara harmonis. Keduanya selalu terlibat dalam ketegangan dan upaya untuk menegasikan keberadaan satu sama lain di hadapan suaminya. Lain kata, keduanya selalu terlibat kontestasi untuk mendapatkan pengaruh dan berusaha meyakinkan suami agar meninggalkan istri yang lainnya. Model yang ketiga ini paling banyak dijumpai dalam pernikahan poligami di Langsa, dan mungkin juga di pelbagai wilayah di Indonesia.

Salah satu contoh adalah poligami Bu Sofyah yang menikah pada akhir 1970-an. Pada 2006 suaminya berpoligami dengan menikahi perempuan yang digambarkan Bu Sofyah sebagai 'bukan perempuan baik-baik'. Saat mengetahui suaminya menikah lagi setelah tiga bulan pernikahan poligami berlangsung, dia segera mencari rumah perempuan tempat tinggal 
ljtihad, Jurnal Wacana Hukum Islam dan Kemanusiaan, Volume 14, No. 1, Juni 2014: 41-63

istri baru suaminya. Di rumah kontrakan istri kedua suaminya dia melampaiskan kemarahan, kendati tidak cukup berhasil meyakinkan, suaminya menceraikan istri barunya dan kembali padanya. Bahkan konflik berujung pada keputusan suami menceraikan Bu Sofyah dengan talak tiga. Sekitar enam bulan kemudian, Bu Sofyah menikah dengan seorang duda, teNamun kemudian bercerai dan rujuk dengan suami sebelumnya setelah bersepakat dirinya bersedia dipoligami (Wawancara Bu Sofyah, November 2011).

Hingga saat penelitian dilakukan, kehidupan rumah tangga Bu Sofyah dan suaminya masih berlangsung dalam kombinasi antara konflik dan harmoni. Selama dua tahun dia dan istri muda suaminya tinggal dalam satu rumah kontrakan dengan dua kamar tidur dengan kamar mandi di luar. Suaminya mengatur penjadwalan tidur bersama para istrinya dan berpindah dari satu kamar ke kamar lainnya setiap hari. Sang suami mengatakan kepada saya meskipun kedua istrinya terlihat bisa akur di depannya, teNamun terkadang di belakangnya mereka berdua sering bertengkar.

Kategorisasi keempat adalah pola di mana secara umum kehidupan keluarga poligami tergolong harmonis, meskipun terkadang diwarnai ketegangan dan kecemburuan antara satu sama lain. Patut disayangkan, selama masa penelitian saya tidak bertemu dengan keluarga yang tergolong harmonis dalam menjalankan pernikahan poligami. Saya memperkirakan relasi antara istri dalam pernikahan poligami yang tergolong harmonis cukup sedikit jumlahnya. Selama penelitian saya tidak menemukannya di Langsa. Terlebih apabila merujuk pada sengketa rumah tangga akibat poligami yang melibatkan figur penceramah terkenal, Abdullah Gymnastiar, yang menjadi perbincangan nasional (Hoesterey, 2012: 96-98), hemat saya kalaupun ada relasi yang harmonis antara para istri dalam keluarga poligami, ini merupakan sebuah perkecualian yang sangat sedikit sekali (Lihat Nurmila, 2009).

\section{Manajemen ekonomi keluarga}

Regulasi di Indonesia mengatur agar suami yang berpoligami dapat memastikan kemampuan berlaku adil secara lahir dan batin terhadap para istri. Bagi sebagian besar suami pelaku poligami dengan status ekonomi kelas menangah ke atas, memperlakukan para istri dengan adil secara lahir barangkali tidak terlalu menjadi persoalan serius, teNamun sebaliknya bagi kalangan masyarakat menengah ke bawah, hal tersebut seringkali menjadi problem. Seringkali 
Berbagi suami atas nama Tuhan: pengalaman keseharian perempuan dipoligami... (Muhammad Ansor)

tindakan suami melakukan poligami berkorelasi positif dengan penurunan kesejahteraan istri pertama karena keterbatasan sumber-sumber ekonomi suami yang harus dibagi bersama para istri mereka. Persoalan ini pula yang seringkali memicu konflik antar istri dalam keluarga poligami.

Kiranya cukup menarik membahas pengelolaan ekonomi dalam keluarga poligami. Jan Pahl (1980: 133-5) mengemukakan setidaknya dua pola pengelolaan ekonomi keluarga, yakni dengan menggunakan pola allowance system, dan kedua pola whole wage system. Kedua pola memperlihatkan konsekwensi yang berbeda terkait dengan pola relasi antara suami dengan istrinya. Allowance system merupakan pola di mana uang belanja dalam sebuah rumah tangga diberikan kepada istri dalam jumlah tertentu sesuai perkiraan umum kebutuhan rumah tangga dalam satu bulan. Apabila ada kebutuhan lain di luar anggaran reguler, maka suami memberikan kembali kepada istrinya. Pola ini memperlihatkan otoritas pengelolaan keuangan keluarga berada di tangan suami.

Adapun pola whole wage system merupakan model di mana pengelolaan keuangan keluarga diserahkan kepada istri. Pada pola ini, suami menyerahkan hampir semua pendapatan ekonominya kepada istrinya. Suami hanya menyisakan sedikit uang yang dia pegang untuk kebutuhannya yang kecil-kecil atau mungkin untuk transportasi ke tempat kerja, untuk biaya rokok atau kebutuhan pertemanannya dalam jumlah yang tidak signifikan. Istri dalam pola ini memegang peranan penting terkait pengelolaan uang dalam keluarga tersebut. Meskipun pada kenyataannya suami tetap memiliki kontrol atas sirkulasi keuangan dalam rumah tangga tersebut, dalam pola ini, istri atau suami tidak akan mengalokasikan uang tersebut dalam jumlah yang signifikan kecuali atas kesepakatan kedua belah pihak.

Sepintas, istri terlihat lebih 'berkuasa' dalam distribusi ekonomi rumah tangga yang menggunakan pola whole wage system. Namun, betapapun memiliki otoritas pengelolaan keuangan keluarga, istri dalam keluarga yang menganut pola pengelolaan whole wage system sesungguhnya tidak memiliki kendali penuh atas sirkulasi keuangan dalam keluarga tersebut. Istri hanya memiliki otoritas melakukan pengelolaan keuangan keluarga sementara keputusan penting tentang arah pemanfaatan keuangan digariskan suami. Singkat kata, kendali utama pengelolaan keuangan tetap berada di tangan suami. 
ljtihad, Jurnal Wacana Hukum Islam dan Kemanusiaan, Volume 14, No. 1, Juni 2014: 41-63

Penelitian ini menemukan sebagian besar suami partisipan poligami di Langsa lebih memilih menggunakan pola allowance system dalam mengelola keuangan keluarga. Beberapa kasus ditemukan bahwa seorang yang sebelumnya menganut sistem whole wage system pun berpindah kepada pola allowance system setelah berpoligami. Bagi suami partisipan poligami, model ini dipilih karena memungkinkan dirinya dapat menentukan keputusan-keputusan penting dalam distribusi keuangan keluarga. Lain itu, hal ini juga didasarkan pada pertimbangan teologis dimana dalam Islam diyakini bahwa suami merupakan pemimpin dalam sebuah keluarga.

Sebuah keluarga poligami di mana suami berprofesi sebagai polisi sementara istri pertama dan kedua tidak bekerja, memilih menerapkan allowance system dalam mengelola keuangan keluarga. Istri pertama menerima alokasi anggaran belanja bulanan dari gaji suami, sementara istri kedua mendapatkan alokasi dari sebagian hasil yang didapatkan di luar gaji resmi. Namun pada saat para istri membutuhkan anggaran tambahan, suami mengalokasikan sejumlah anggaran tertentu sesuai dengan keperluan para istri dengan mempertimbangkan kondisi keuangan sang suami.

Pak Sofyan, seorang partisipan poligami dengan latar-belakang ekonomi yang lebih tepat dikelompokkan sebagai golongan menengah ke bawah juga menggunakan allowance system. Untuk memenuhi kebutuhan sehari-hari, Pak Sofyan berjualan rujak keliling dengan satusatunya sepeda motor yang dia miliki. Istri pertama Pak Sofyan berjualan makanan ringan pada sebuah kantin di salah satu kampus di Langsa. Adapun istri kedua Pak Sofyan pernah berjualan rujak di kampus yang sama, Namun belakangan menjadi petugas parkir di sebuah apotik di kota yang sama. Istri pertama Pak Sofyan mengaku sehari-hari dia bisa menyisihkan keuntungan sebesar Rp. 25.000 dari hasil jualan, sementara Pak Sofyan mengaku dapat menyisihkan keuntungan rata-rata sebesar Rp. 50.000 dalam sehari. Dari penghasilan harian ini Pak Sofyan membaginya kepada dua orang istrinya, setelah menyisakan untuk keperluan pribadinya.

Penelitian ini menemukan sebagian besar suami pelaku poligami mengontrol sendiri keuangan keluarga dengan menerapkan allowance system dalam pengelolaan ekonomi keluarga. Kontrol keuangan keluarga di tangan suami sebetulnya fenomena umun dalam lingkungan masyarakat yang masih menganut budaya patriarkhi, namun dalam keluarga poligami sering ditemukan kontrol tersebut lebih ketat dibandingkan dengan yang ditemukan pada keluarga 
Berbagi suami atas nama Tuhan: pengalaman keseharian perempuan dipoligami... (Muhammad Ansor)

non-poligami. Fenomena ini meneguhkan kesimpulan Blackburn (2004: 116-7) tentang tingginya tingkat ketergantungan istri terhadap suami di Indonesia.

\section{Artikulasi adil dalam keluarga poligami}

Sementara sebagian suami partisipan poligami berusaha mengartikulasikan konsep adil terhadap para istri mereka semirip mungkin dengan ketentuan-ketentuan yang diyakini sebagai pandangan Islam, sebagian lainnya tidak terlalu memedulikan petunjuk-petunjuk agama yang menuntut berlaku adil terhadap para istri mereka. Sebagian Muslim meyakini kemampuan berbuat adil sebagai salah satu hal yang harus dipertimbangkan sebelum seorang suami melakukan pernikahan poligami. Meskipun sebagian lainnya meyakini Islam memberikan kebebasan kepada para suami menikahi maksimal empat orang perempuan tanpa mempertimbangkan kemampuan berlaku adil terhadap para istri.

Selain itu, peraturan perundang-undangan di Indonesia juga mengharuskan suami menandatangani surat pernyataan mampu berbuat adil sebagai salah satu perlengkapan administratif yang harus dilengkapi ketika seseorang mengajukan izin poligami. Seorang suami yang ingin mendapatkan izin poligami dari pengadilan diharuskan mampu meyakinkan pengadilan bahwa dirinya mampu berlaku adil kepada para istri mereka baik secara batin maupun lain (Mulia, 2005). Kemampuan berlaku adil bagi sebagian besar orang diyakini berkorelasi positif dengan terjaminnya kebahagiaan pasangan yang berpoligami.

Salah satu indikator untuk mengukur artikulasi adil terhadap para istri dipoligami adalah pembagian roster antara suami dengan para istrinya di malam hari. Peneliti sedikitnya menemukan tiga pola roster yang digunakan para suami pelaku poligami di Langsa. Sebagian suami menetapkan jadwal yang ketat, ada yang membuat roster secara fleksibel, sementara sebagian lainnya tidak memiliki jadwal berpola atau hanya melakukan kunjungan kepada para istrinya secara random. Ada beragam faktor yang berkolerasi dengan keragaman pola penjadwalan yang dilakukan suami terhadap para istrinya. Seorang yang berpoligami dengan sepengetahuan istri pertama, memiliki karakter penjadwalan yang berbeda dengan poligami yang dilakukan di luar sepengetahuan istri pertama. Demikian pula perbedaan usia masingmasing istri, atau penampilan istri dipercaya berpengaruh terhadap durasi waktu yang akan disediakan suami kepada istri bersangkutan. Sudah menjadi perkiraan umum semakin muda, 
ljtihad, Jurnal Wacana Hukum Islam dan Kemanusiaan, Volume 14, No. 1, Juni 2014: 41-63

cantik dan menyenangkan seorang istri, maka suami akan semakin banyak mengalokasikan waktu untuk dirinya.

Seorang partisipan poligami di Sei Pauh menggunakan sistem penjadwalan yang ketat terhadap para istrinya. Ia membagi malam-malam bersama istrinya masing-masing tiga malam, dan bergiliran terus secara simultan. Suami menerapkan toleransi yang rendah terhadap situasi-situasi tertentu di mana misalnya salah seorang istri pada suatu waktu lebih membutuhkan kehadiran suami dibandingkan istri yang lainnya. Relasi antara para istri tersebut tergolong harmonis, keduanya kadang terlibat dalam suatu aktivitas tertentu secara bersamasama.

Partisipan poligami yang tidak membuat jadwal yang ketat dalam mengunjungi para istri antara lain dilakukan Pak Sofyan. Kedua istri Pak Sofyan selama dua tahun pernah tinggal satu rumah, sebelum akhirnya istri pertama memutuskan untuk mengontrak rumah sendiri. Pak Sofyan menceritakan dirinya tergolong menerapkan sistem yang fleksibel dalam membagi jadwal terhadap para istrinya. Saat kedua istrinya masih tinggal satu rumah, Pak Sofyan menggilir jadwal tidur bersama istrinya secara bergantian dengan pola tidak teratur. Namun setelah para istrinya tinggal di rumah berbeda, dirinya membagi jadwal kunjungan meskipun seringkali tidak ditaati. Biasanya Pak Sofyan selama dua sampai tiga hari bersama istri pertama, sementara empat sampai lima hari sisanya digunakan untuk bermalam di rumah istri kedua. Namun terkadang dirinya menghabiskan malam harinya selama seminggu bersama istri kedua.

Model ketiga adalah suami yang tidak memiliki sistem penjadwalan kunjungan dengan para istri. Dua dari enam partisipan poligami di desa Seulalah tidak memiliki penjadwalan khusus terkait kunjungan terhadap para istri. Seorang istri di Seulalah yang berstatus istri kedua sesekali menerima kunjungan suaminya meskipun tanpa jadwal yang baku. Suami yang merupakan salah seorang pegawai di instansi pemerintah daerah di luar Langsa lebih banyak menghabiskan waktu di rumah istri pertama. Seorang partisipan poligami lainnya di Seulalah justru lebih banyak menghabiskan waktu di rumah istri kedua, dan hampir tidak pernah terlihat berada di rumah istri pertama. Pada kasus keluarga yang disebutkan terakhir, tidak adanya kunjungan suami terhadap istri pertama karena suami tidak bersedia menceraikan istri pertama sementara istri pertama tidak dapat menerima keputusan suaminya berpoligami. 
Berbagi suami atas nama Tuhan: pengalaman keseharian perempuan dipoligami... (Muhammad Ansor)

Meskipun secara kuantitatif upaya-upaya berlaku adil sering berhasil dipenuhi suami partisipan poligami, ketercapaian substansi keadilan dalam perspektif para istri merupakan suatu hal yang sangat sulit dipenuhi. Petikan wawancara berikut barangkali bisa menggambarkan kerumitan tersebut.

[...] Saya lalu bagi sama istri muda 4 malam, sama yang tua sisanya. Saya bilang ke istriistri saya, kalau membagi urusan zahir dan batin, dan terutama batin, itu tergantung kemampuan saya. Kalau sanggup saya layani kamu, kalau lagi gak sanggup saya, saya berhenti dulu. Saya bilang lagi: mungkin kalian kurang puas sama saya karena satu minggu cuma dapat sekian kali, carilah suami lain. Kenapa, bagi saya, dibidang kebatinan itu adalah suami yang menentukan, bukan wanita. Kalau yang wanita maunya 20 kali tiap malam dia pun tahan. Wanita ini kan hanya tinggal menahan saja, sementara kalau lakilaki inikan harus menghidupkan [...] Mungkin kau mau melayani saya sampai sepuluh kali bisa, namun aku tak bisa layani kamu. Begitu saya bilang sama istri yang tua.... Saya katakan sama dia: kalau kau minta sama saya satu malam dua kali [saya tak bisa].. Saya manusia, bukan besi, bukan robot [...] (Wawancara Pak Sofyan, 14 November 2011).

Kemungkinan suami mampu mengartikulasikan konsep adil dalam keluarga poligami ditolak mentah-mentah Bu Wati, seorang perempuan yang memilih perceraian saat suaminya berpoligami. Menurutnya, adil merupakan urusan batin seorang perempuan, karenanya hal tersebut tidak dapat diukur. Bu Wati mengaku ketika melihat suaminya berboncengan dengan perempuan lain saja dirinya sudah tidak dapat mengontrol perasaan, sehingga bagaimana mungkin dirinya bisa menjalani kehidupan dimana suaminya menjadwal malam-malam hari antara dirinya dengan perempuan lain. Karena itu, Bu Wati memilih mengajukan gugatan perceraian di pengadilan ketika suaminya tetap meneruskan rencana melakukan poligami.

\section{Istri dalam perayaan Idul Fitri dan Idul Adha}

Perayaan hari raya merupakan bagian dari kehidupan keluarga sehari-hari (Altman, 1996:318). Bagi Muslim Aceh, dan juga umumnya Muslim di Indonesia, 'Idul Fitri dan 'Idul Adha merupakan momen hari besar yang selalu diperingati secara meriah. Pada kedua hari raya tersebut, orang Aceh saling mengunjungi keluarga satu sama lain (Lihat Hurgronje, 1985: 267-71). Dewasa ini orang Aceh bahkan memperingati hari raya idul Adha secara lebih meriah dibandingkan dengan peringatan hari raya 'Tdul Fitri. Karena itu pemerintah 
ljthad, Jurnal Wacana Hukum Islam dan Kemanusiaan, Volume 14, No. 1, Juni 2014: 41-63

daerah di Aceh menerbitkan pengumuman hari libur untuk hari raya idul Adha dengan menambah satu atau dua hari dari pengumuman libur resmi.

Keberadaan suami dalam momentum hari raya merupakan peristiwa penting dalam kehidupan keluarga poligami (Nurmila, 2009:131-132). Tidak jarang konflik dalam rumah tangga keluarga poligami terjadi karena soal menentukan dimana suami merayakan hari raya. Hal ini karena keputusan suami untuk menentukan tempat dimana dia akan merayakan hari besar tersebut merupakan ekspresi simbolis tentang siapa yang dinilai lebih penting diantara para istrinya. Kasus Zainab dengan suaminya, Maulud, mengindikasikan hal ini. Berdasarkan dokumen persidangan di Mahkamah Syariah, Zainab (istri kedua) bertengkar dengan suaminya saat mengetahui istri pertama menelpon agar sang suami merayakan lebaran di rumahnya (istri pertama).

Umumnya partisipan poligami dalam penelitian ini memperingati hari raya, baik 'Idul Fitri maupun 'Idul Adha di rumah istri pertama. Hanya sebagian kecil suami memperingati hari raya di rumah istri kedua. Terkadang memperingati hari raya di rumah istri kedua dilakukan karena konflik antara suami dengan istri pertama sedang memuncak sehingga tidak memungkinkan bagi mereka merayakan hari raya bersama. Setelah memperingati hari raya di rumah istri pertama, maka dua atau tiga hari berikutnya suami pergi ke rumah istri kedua. Seorang suami partisipan poligami di Sei Pauh, Kecamatan Langsa Barat misalnya memilih memperingati hari raya pertama bersama istri pertama dan anak-anaknya sementara istri yang kedua memperingati hari raya dengan pulang ke rumah orang tuanya. Aktivitas ini dilakukan rutin sejak poligami berlangsung.

Namun ada beberapa perkecualian. Seorang anggota kepolisian di Seulalah yang berpoligami tidak selalu merayakan hari raya di rumah istri pertama. Terkadang dia berada di rumah istri pertama, namun juga terkadang berada di rumah istri kedua. Bagi seorang anggota kepolisian sudah barang tentu akan sangat mudah untuk menentukan tempat di mana dia akan merayakan hari raya pertama tanpa adanya tekanan sosial dari publik di sekitarnya, karena dalam anggapan publik, seorang polisi bisa saja sedang bertugas di luar daerah saat hari raya.

Terdapat perubahan kecenderungan pola perayaan hari raya 'Idul Fitri bagi beberapa partisipan poligami dalam penelitian di Langsa. Seorang suami pada saat masih berstatus 
Berbagi suami atas nama Tuhan: pengalaman keseharian perempuan dipoligami... (Muhammad Ansor)

keluarga monogami dalam merayakan 'Idul Fitri biasanya mengunjung keluarga dari pihak kedua istri sehingga membutuhkan waktu beberapa hari. Hal ini bagi sebagian orang tidak mungkin dilakukan apabila kunjungan ke para saudara membutuhkan waktu misalnya lebih dari tiga hari. Sebab, pada hari kedua atau ketiga, biasanya seseorang yang sudah menjadi partisipan keluarga poligami harus berada di rumah istrinya yang kedua, sementara seringkali istri kedua berada di tempat yang berbeda dengan tempat tinggalnya.

\section{Perkembangan anak dalam keluarga poligami}

Terdapat penilaian yang berbeda-beda menyangkut dampak negatif yang ditimbulkan pernikahan poligami terhadap pertumbuhan anak. Omar Khasawneh (2011) dalam penelitian yang dilakukan di Jordan menyimpulkan poligami tidak menimbulkan dampak negatif yang signifikan terhadap perkembangan anak. Berbeda dengan Khasawneh, Nurmila (2009:138) berpandangan 'poligami tidak hanya berdampak terhadap perkembangan ekonomi dan emosi istri, namun juga anak-anak dari pasangan poligami'. Perbedaan ini diperkirakan karena poligami di Jordan diterima baik secara legal maupun sosial, sementara praktik poligami di Indonesia diterima secara legal, namun dipersoalkan secara sosial.

Saya akan memperlihatkan dampak negatif poligami terhadap pola relasi antar anak dalam keluarga dengan ibu yang berbeda. Salah satu contohnya adalah poligami yang dilakukan Pak Sofyan, suami Bu Sofi. Pak Sofyan memiliki tujuh anak dari istri pertama, tiga diantara belum menikah saat dirinya berpoligami, yakni Wulan (17 tahun), dan Rahmad (12 tahun). Sementara itu, istri kedua Pak Sofyan adalah janda dengan tiga anak: yakni, Nurul (19 Tahun), Bahtiar (12 Tahun) dan Nur Sapna (4 tahun). Saat penelitian berlangsung, pernikahan Pak Sofyan dengan istri kedua menghasilkan satu orang anak (Nursaleha, 2,5 tahun).

Konflik antara Bu Sofi (istri pertama) dengan Pak Sofyan karena poligami mengakibatkan Wulan kehilangan kesempatan satu tahun untuk melanjutkan sekolah. Saat orang tuanya berpisah, Wulan dibawa Bu Sofi pindah ke Aceh Tengah. Kehilangan kesempatan ini sangat berpengaruh terhadap pertumbuhan kepribadian Wulan. Hubungan antara Wulan dengan Nurul dan ibunya juga berlangsung secara tidak harmonis. Wulan menganggap Nurul dan ibunya sebagai pihak yang paling bertanggung jawab dalam merampas kebahagiaan keluarganya. Menurut Pak Sofyan dan Bu Sofi, Nurul dan Wulan dalam empat tahun terakhir 
ljtihad, Jurnal Wacana Hukum Islam dan Kemanusiaan, Volume 14, No. 1, Juni 2014: 41-63

tidak pernah bertegur sapa ketika mereka bertemu.

Poligami Pak Sofyan juga berpengaruh terhadap perkembangan pendidikan anak-anaknya yang lain. Kedua anak Pak Sofyan, yakni Lukman (anak kandung) dan Bahtiar (anak tiri) dititipkan di sebuah Panti Asuhan di Gampang Jawa Belakang. Namun, bagi Bu Sofi, menempatkan anaknya (Lukman) di panti asuhan bukan langkah yang tepat. Bu Sofi tidak habis pikir dengan sikap suaminya yang memilih menempatkan anak kandungnya di Panti Asuhan sementara dua anak tirinya (Nurul dan Nur Sapna) tinggal serumah dengan dirinya. Bagi Bu Sofi, membiarkan anak sendiri di panti asuhan untuk mengasuh "anak orang lain" merupakan cerminan sikap suami yang kurang bertanggung jawab. Keputusan menempatkan Lukman di panti asuhan selalu menjadi sumber sengketa antara Ibu Sofi dengan suaminya.

Poligami juga berdampak negatif terhadap pendidikan anak pasangan Bu Wati dan Pak Syahrur. Bu Wati lebih memilih mengajukan gugatan cerai daripada dipoligami. Saat itu Bu Wati dan Pak Syahrur sudah memiliki tiga orang anak: anak pertama baru menyelesaikan SLTA, anak kedua sedang menempuh pendidikan tingkat SLTP di sebuah pesantren di Banda Aceh, dan anak ketiga menempuh pendidikan tingkat dasar di Langsa. Ketika terjadi konflik antara kedua orang tuanya terkait rencana poligami, suaminya mengancam akan mengeluarkan anaknya dari pesantren dan menghentikan anggaran pendidikan anaknya. Ancaman itu kemudian terbukti, setelah mereka bercerai, anak keduanya dipulangkan dari pesantren, sementara anak ketiga tinggal bersama Ibunya di Langsa.

Dampak poligami juga dialami Malizar (32 tahun), anak pertama Pak Madjid (80 tahun) dengan istri keduanya, Rosniar (60 tahun). Malizar menceritakan, ayahnya berpoligami karena ingin mendapatkan anak perempuan. Poligami Pak Madjid mulanya tanpa sepengetahuan istri pertama. Namun tiga tahun kemudian pernikahan poligami tersebut terbongkar. Istri pertama Pak Madjid meminta agar suaminya tidak pernah membawa istri keduanya ke desanya di Aceh Timur. Komitmen tersebut berhasil dijalani sehingga sampai mahasiswa, Malizar tidak pernah dibawa ke kampung halaman ayahnya. Malizar bertemu pertama kali dengan Ibu tirinya ketika sudah mahasiswa.

Pernikahan poligami Pak Madjid mengakibatkan ketidakharmonisan hubungan antara anak-anak Pak Madjid dari istri pertama dan istri kedua. Sebagai seorang toke beras di Aceh Timur dengan usaha yang sangat berkembang pesat, Pak Madjid tergolong berkecukupan 
secara ekonomi. Namun Pak Madjid lebih memprioritaskan alokasi sumber-sumber ekonominya kepada keluarga dari istri pertama. Secara faktual memang terlihat ketimpangan sosial ekonomi antara keluarga Pak Madjid dari istri pertama dan istri kedua, demikian pula dengan kondisi ekonomi anak-anaknya. Anak pertama Pak Madjid dari istri pertama sekarang dipercaya mengelola usaha ayahnya, anak keduanya menyelesaikan doktor di luar negeri atas dukungan biaya dari keluarga dan sekarang bekerja di pemerintah daerah di Aceh. Adapun anak ketiga Pak Madjid saat ini menjabat sebagai Sekretaris Gampong di desanya di Perlak. Malizar menceritakan salah satu alasan dirinya melanjutkan kuliah program pascasarjana adalah merupakan strategi agar dirinya dapat mengakses fasilitas ekonomi ayahnya dengan alasan biaya perkuliahan, sebagaimana dilakukan abangnya dari ibu yang berbeda.

Menurut Malizar, dalam kultur masyarakat Aceh, pada saat anak dari istri kedua tidak pernah diperkenalkan oleh suami kepada istri pertama, maka kesempatannya untuk mendapatkan akses ekonomi dari orang tuanya menjadi lebih terbatas. Pada saat pernikahan, Malizar membiayai sendiri kebutuhan pernikahannya. Ini berbeda dengan sikap ayah Malizar terhadap anak-anaknya dari istri pertama yang relatif lebih mendapatkan akses ekonomi dari orang tuanya. Hal ini, kata Malizar ditunjukkan dengan sikap orang tua yang menyerahkan bisnisnya kepada anak pertamanya.

Ketimpangan akses ekonomi dari orang tua yang dialami Malizar menandakan akses ekonomi anak hasil poligami cenderung berbeda dengan anak dari istri pertama. Bagi Malizar, hal ini berpengaruh terhadap perkembangan kepribadiannya dan corak pembentukan identitasnya. Meskipun Malizar merupakan anak yang lahir dari pasangan orang tua laki-laki dari Aceh dan Ibu dari Batak, Malizar lebih suka mengidentifikasi diri sebagai orang Batak. Di depan publik dirinya lebih suka memperkenalkan diri dengan identitas ke-Batak-kannya dibandingkan dengan ke-Acehan-nya. Malizar sering dipesankan Ibunya agar jangan sampai menikah dengan perempuan yang seetnis dengan orang tuanya, karena pengalaman pahit yang dirasakan Ibunya. Meski belakangan Malizar justru menikahi dengan orang Aceh.

Narasi di atas memperlihatkan poligami menimbulkan dampak negatif terhadap perkembangan anak. Pernikahan poligami dalam keluarga Pak Sofyan, Pak Syahrur, dan Pak Madjid misalnya memperlihatkan efek negatif terhadap perkembangan anak-anak mereka. Memang pada kasus Pak Madjid, anak-anaknya dari istri pertama tidak menerima 
ljthad, Jurnal Wacana Hukum Islam dan Kemanusiaan, Volume 14, No. 1, Juni 2014: 41-63

dampak negatif secara ekonomi, Namun efek negatif secara ekonomi justru dirasakan anak-anaknya dari istri kedua.

\section{Simpulan}

Salah satu tujuan pernikahan dalam Islam adalah membentuk keluarga sakinah. Namun, berdasarkan penelitian di atas, tujuan ideal tersebut sulit diwujudkan keluarga yang terlibat pernikahan poligami. Berbagi suami, kendati pun dilakukan atas nama berburu perkenan Tuhan, seringkali menjadi petaka dalam pernikahan.

Bukannya melempangkan jalan pembentukan keluarga sakinah, poligami justru menjadi sumber persoalan rumah tangga dan ketidakkeharmonisan sosial. Kehidupan rumah tangga keluarga poligami selalu diwarnai dengan ketegangan dan konflik. Hasil penelitian menemukan interaksi antara sesama istri dipoligami umumnya tidak harmonis. Meskipun barangkali ditemukan keluarga poligami yang berhasil membangun rumah-tangga harmonis, namun kasus yang demikian ini merupakan perkecualian yang jarang ditemukan. Penelitian ini juga memperlihatkan bahwa konsep adil dalam pemenuhan kebutuhan batin (seksual) dan zahir (ekonomi) sangat sulit diwujudkan suami partisipan poligami. Tidak hanya terhadap perempuan (istri), poligami juga berdampak terhadap perkembangan anak-anak. Konflik antar anak dari hasil pernikahan poligami seringkali menjadi trauma yang mendalam dan mengganggu jalan terwujudnya keluarga harmonis yang dicitakan Islam.

Penelitian ini mementahkan anggapan umum bahwa poligami merupakan solusi yang ditawarkan Islam (Nasir, 2009; Irawan, 2007). Sejalan dengan itu penelitian merekomendasikan pihak-pihak terkait, terutama pemerintah, untuk melakukan dua hal. Pertama, mempertimbangkan perlunya menerbitkan peraturan yang lebih ketat mengenai mekanisme perizinan poligami; dan kedua, memberi sanksi hukum yang tegas terhadap pasangan poligami yang melakukan pernikahan tanpa mengikuti prosedur yang ditetapkan pemerintah. Melalui mekanisme ini diharapkan dampak negatif poligami dapat diminimalisir.

Mengakhiri tulisan, sebagai refleksi atas keterbatasan penelitian ini, saya ingin mengemukakan dua hal. Pertama, penelitian tentang praktik poligami dalam komunitas Muslim idealnya dilakukan dalam bentuk tim penelitian yang melibatkan anggota laki-laki dan perempuan. Pembelajaran saya selama melakukan penelitian adalah adanya hambatan kultural 
Berbagi suami atas nama Tuhan: pengalaman keseharian perempuan dipoligami... (Muhammad Ansor)

saat pengumpulan data lapangan, terutama ketika mewawancarai perempuan atau para istri yang dipoligami. Hal ini mengingat dalam budaya masyarakat di Langsa dan mungkin juga tempat lain di Indonesia, seorang informan akan lebih terbuka dalam menyampaikan informasi kepada orang lain yang berjenis kelamin serupa. Kedua, penelitian dengan tema serupa perlu kembangkan dalam cakupan area studi yang lebih luas agar menghasilkan potret yang relatif lebih utuh mengenai dampak negatif poligami. Ini penting agar hasil penelitian dengan tema ini memiliki argumentasi yang lebih meyakinkan untuk dijadikan landasan pembaharuan hukum perkawinan di Indonesia.

\section{Daftar pustaka}

Adnan, Gunawan. Women and the Glorious Qur'an: An Analytical Study of Women-Related Verses of Sura An-Nisa'. Göttingen: Universitätsdrucke Göttingen, 2004.

Altman, Irwin dan Joseph Ginat. Polygamous Families in Contemporary Society. New York: Cambigde University, 1996.

Aminah, Siti, "Cerai Gugat di Langsa: Studi tentang Faktor-faktor Cerai Gugat di Mahkamah Syar'iyyah Kota Langsa pada 2010", Skripsi diajukan pada Program Studi Akhwal alSyakhsiyyah, STAIN Zawiyah Cot Kala Langsa, 2011.

Ansor, Muhammad, Zubir dan Muhammad Abu Bakar. Religiusitas dan Sikap atas Penerapan Syariat Islam di Kota Langsa. Langsa: LP3M STAIN Zawiyah Cot Kala, 2010.

Blackburn, Susan. Women and the State in Modern Indonesia. Cambridge: Cambridge University Press, 2004.

Chin, Grace V.S. “Imagined Subjects: Polygamy, Gender and Nation in Nia Dinata's Love for Share”, Journal of International Women's Studies, Vol. 13, No. 3 (Juli 2012): pp. 137-152.

Erricker, Clive, "Pendekatan Fenomenologis", dalam Aneka Pendekatan Studi Agama. Jogyakarta: LKiS, 2002.

Hoesterey, James B., "Pemasaran Moralitas: Naik, jatuh, dan Pembentukan Ulang CapMerek As Gym”, dalam Fealy, Greg dan Sally White (ed.), Ustadz Seleb, Bisnis Moral dan Fatwa Online: Ragam Ekspresi Islam Indonesia Kontemporer. Jakarta, Komunitas Bambu: 2012.

Hicks, Sarah, “The Maligned, Maltreated Madu: Female Experiences of Polygyny in Three Romantics Syair”, Indonesia and the Malay World, 36:104 (2008): pp. 47-66. DOI: 10.1080/ 13639810802016521.

Hurgronje, Snouck. Aceh di Mata Kolonialis. Jakarta: Yayasan Soko Guru, 1985. 
ljthad, Jurnal Wacana Hukum Islam dan Kemanusiaan, Volume 14, No. 1, Juni 2014: 41-63

Irawan, Chandra Sabtia. Perkawinan dalam Islam: Poligami atan Monogami?. Yogyakarta: anNaba, 2007.

Khasawneh, Omar M, Abdul Hakeem Yacin Hijazi, Nassmat Hassan Salman, "Polygamy and its Impact on the Upbringing of Children: A Jordanian Perspective", Journal of Comparative Family Studies, Vol 42, No. 4 (2011): 563-XVI.

Lombard, Denys. Kerajaan Aceh Zaman Sultan Iskandar Muda 1607-1636. Jakarta: KPG, 2008.

Mahmood, Saba. Politics of Piety: The Islamis Revival and the Feminist Subject. Princeton and Oxford: Princeton University Press, 2005.

Mernissi, Fatima. Beyond the Veil: Dinamika Pria Wanita dalam Masyarakat Modern. Surabaya: Al-Fikri, 1997.

Mernissi, Fatima. Pemberontakan Wanita: Peran Intelektual Kaum Wanita dalam Sejarah Muslim. Bandung: Mizan, 1999.

Mulia, Siti Musdah. Muslimab Reformis: Perempuan Pembaharu Keagamaan. Jakarta: Mizan, 2005.

Nasir, Jamal JA. The Status of Women under Islamic Law and Modern Islamic Legislation. Leiden: Brill, 2009.

Nurmila, Nina. Women, Islam and Everyday Life: Renegosiation Polygamy in Indonesia. London and Now York: Routlegde, 2009.

Pahl, Jan, "Patterns of Money Management within Marriage", Journal of Social Science Policy 9, 1980.

Rhouni, Raja. Secular and Islamic Feminist Critique in the Work of Fatima Mernissi. Leiden: Brill, 2010.

Robinson, Kathryn. Gender, Islam and Democracy in Indonesia. London and New York: Routlegde, 2009.

Scott, James C. Domination and the Art of Resistance: Hidden Transcripts. London: Yale University Press New Haven and London, 1990.

Vignato, Silvia, "Men Come in, Men Go Out: Single Muslim Women in Malaysia and Aceh", Social Identities: Journal for the Study of Race, Nation and Culture, 18:2 (2012): pp. 239-57. DOI : 10.1080/13504630.2012.652847.

Yamani, Maha A.Z. Polygamy and Law in Contemporary Saudi Arabia. New York: Ithaca Press, 2008.

Zeitzen, Miriam Koktvedgaard. Polygamy A Cross-cultural Analysis. New York: Berg, 2008.

Dokumen Persidangan

Banyaknya Perkara yang Diterima dan Diputus Mabkamah Syariah Langsa Perbulan, Dokumen Mahkamah Syariah Kota Langsa, 03 Januari 2011, tidak dipublikasikan. 
Berbagi suami atas nama Tuhan: pengalaman keseharian perempuan dipoligami... (Muhammad Ansor)

Dokumen Gugatan Perceraian di Mabkamah Syariah Langsa Tabun 2010, Nomor Register 03, 60, 78, 96, 98, 185, 117, 118, 119, 138, 140, 148, 155, 161, 201, 212, 220, dan 223.

Dokumen Permohonan Izin Poligami di Mabkamah Syariah Langsa Tabun 2011, Nomor Register 97.

Dokumen Permohonan Izin Poligami di Mabkamah Syariah Langsa Tabun 2010, Nomor Register 03.

Faktor-faktor Penyebab Terjadinya Perceraian Perbulan di Langsa Tabun 2010, Dokumen Mahkamah Syariah Kota Langsa, 03 Januari 2011, tidak dipublikasikan.

Laporan Tabun 2010 Mabkaman Syariab Langsa tentang Perkara Yang Diterima, Dokumen Mahkamah Syariah Langsa, 03 Januari 2011, tidak dipublikasikan.

Wawancara

Hindun (46 tahun), Istri Pertama, Langsa, 12, 18 November 2011.

Malizar (32 tahun), Anak Dari Istri Kedua, Langsa, 19 November 2011.

Mandar (52 tahun), Istri Pertama, Langsa, 12 November 2011.

Nurman (50 tahun), Imam Musholla Seulalah, di Langsa, 24 Desember 2011.

Rusniah (20 tahun), Mahasiswa, di Langsa, 28 November 2011.

Sodiah (44 tahun), Istri Kedua, Langsa, 15, 24 November 2011.

Sofi (48 tahun), Istri Pertama, Langsa, 28, 30, Oktober 15, 24 November 2011.

Sofyan (50 tahun), Suami Partisipan Poligami, Langsa, 14 November 2011.

Wati (36 tahun), Janda Cerai Karena Poligami, Langsa, 24 Desember 2011.

Zubir (38 tahun), Akademisi, di Langsa, 24 Desember 2011. 